https://doi.org/10.48009/1_iis_2007_44-51

\title{
MARKETING IS TO THE ADULT STUDENT
}

\author{
Jeanne M Baugh, Robert Morris University, baugh@rmu.edu \\ Paul J Kovacs, Robert Morris University, kovace@rmu.edu \\ Frederick G Kohun, Robert Morris University, kohun@rmu.edu \\ Walter Pilof, Robert Morris University, pilof@rmu.edu
}

\begin{abstract}
Adult learners are becoming a growing population on campuses around the country. The adult student is looking for a flexible and fast paced program that will allow him to finish a degree quickly without giving up his life. He is balancing home, family, job and school while not wanting any area to suffer. Many institutions are making student satisfaction a priority. Acknowledging that the satisfaction experienced by the adult student will differ from that experienced by the traditional age student is a key to successful competition for the enrollment and retention numbers. This paper describes the process of the creation of an Information Systems Degree marketed specifically to the adult learner. Among the areas addressed are, adult student needs, faculty input and reservations, curriculum design and administrative support.
\end{abstract}

Keywords: Adult learner, Marketing IT, Degree completion

\section{INTRODUCTION}

Robert Morris University is a private institution in Pittsburgh, Pennsylvania. There is a large residential campus near the airport as well as several satellite locations, including a site in the middle of down town Pittsburgh. The down town site has basically become an evening and adult location. The traditional undergraduate degrees presented by the Computer and Information Systems Department include:

- Bachelor of Science in Computer Information Systems

- Bachelor of Science in Competitive Intelligence Systems

- Bachelor of Science in Information Science With all of the above degrees, the student must also choose a concentration. These concentrations include:

- Health Care Systems

- Network Administration

- Office Information Systems

- Security

- Web Development
- Software Development

- General

- Business

The student also defines an area of interest (other than IS courses). The area of interest is approved by the student's advisor. It must be noted that the student must also complete all requirements in the Robert Morris University core.

Both the Bachelor of Science in Computer Information Systems and the Bachelor of Science in Information Sciences are accredited by the Accreditation Board of Engineering Technology Computing Accreditation Commission (ABETCAC).

The Information Systems student enrollment has decreased in the last five years. This is not unusual, as many institutions nation wide are experiencing this decline. But IT jobs are out there, so the enrollment numbers should be on the increase in the near future. "IT and tech companies have begun to worry that there will not be enough skilled IT professionals to meet the demands of growing job positions. This is partly due to the fact that fewer students are going for degrees in the computer science field". [3] Traditionally, the Information Systems Department was healthy in the number of adult students it attracted. The mean age for a student in the program was 25. But all numbers have been falling off, both the traditional age and the adult learner. This paper addresses the problem of the dwindling adult numbers. Basically stated, the Computer and Information Systems Department was loosing adult students to other institutions in the geographic area. There was no marketing towards the adult IS student. But was there something to market? This was an area that needed to be addressed if the program was to survive.

\section{IT EMPLOYMENT FORECAST}

The IT employment outlook is not bleak, especially in the Pittsburgh area. Examples of employment trends in IT include:

- Certification Magazine [1] 
o JupiterMedia prediction of an increase of 12 percent of IT jobs

o US gained 128,000 IT jobs from 20042005, a 3.9 percent growth rate

- US Department of Labor, Bureau of Labor Statistics [9]

o Computer occupation expected to grow from 3,152,800 in 2004 to 4,198,000 in 2014 (increase of 30.7 percent)

o Information Technology increase second only to Health care profession (33.7 percent increase)

- US Department of Labor and Labor Statistics Occupational Outlook Handbook 2006-2007 [8]

o Computer and healthcare occupations are expected to grow fastest than the average growth rate from 2006-2007

o Computer occupations account for 5 out of the 20 fastest growing occupations

o 17 computer/healthcare occupations combined will add more than 1.8 million new jobs

o 8.1 percent increase forecasted for jobs of Managers of Information Systems in the Pittsburgh PA area

- Occupational Employment in Computer and Information Systems (counties in western Pennsylvania)[6]

o Current all related occupation employment totals - estimated 1,199,460 - projected 1,197,660

o Computer and math occupations estimated 23,140 - projected 26,680 (change of 15.3 percent)

- Figure 1. shows IT hiring projections for the second quarter of 2007

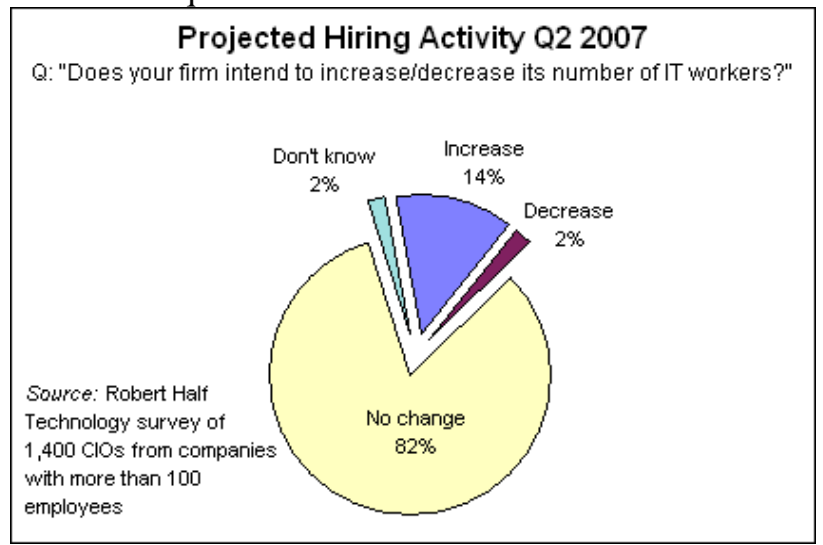

Figure 1. Robert Half Technology [6]

These examples show that the reduction in IT jobs has bottomed out and the trend is for an increase in employment. The student numbers should reflect this. This paper does not address the traditional undergraduate student recruitment, but it does focus on the prospective adult student.

\section{THE ADULT LEARNER}

The adult student obviously differs from the traditional age student and is looking for different elements in his education. [5] Institutions of higher education must recognize this. Universities must no longer have an arrogance concerning the way they do business. Even thou some of us teaching Information Systems at the College level might not like it, the adult student sees himself as a customer. Thus he will shop around for a higher education institution much as he would shop around for a new car. Adults are looking for a wide range of services from the institution. [10] The institution who meets their needs best with get their business. Students are very clear about what they want and are not afraid to demand it. [4] Which College will give them the most bang for their buck? In a study conducted in 2005 by Noel-Levitz, [5] the areas that are most important to the adult learner as well as those they are most satisfied with are summarized in table 1.

\begin{tabular}{|l|l|l|}
\hline AREA of Concern & $\begin{array}{l}\text { Importance } \\
\text { Mean }\end{array}$ & $\begin{array}{l}\text { Satisfaction } \\
\text { Mean }\end{array}$ \\
\hline Outreach & 6.47 & 5.68 \\
\hline $\begin{array}{l}\text { Life and Career } \\
\text { Planning }\end{array}$ & 6.31 & 5.21 \\
\hline $\begin{array}{l}\text { Teaching-Learning } \\
\text { Process }\end{array}$ & 6.25 & 5.66 \\
\hline Financing Support & 6.10 & 5.34 \\
\hline $\begin{array}{l}\text { Student of } \\
\text { Systems }\end{array}$ & 6.94 & 5.33 \\
\hline Technology & 5.21 \\
\hline $\begin{array}{l}\text { Assessment Learning Outcomes } \\
\text { Lab }\end{array}$ & 5.18 \\
\hline
\end{tabular}

Table 1. Adult Learner Inventory $(7=$ very important/very stratified $1=$ not important/not satisfied)

This data shows that institutions must pay attention not only to attracting the adult student, but to retaining that student. Further data from the NoelLevitz study also suggests that the enrollment factors for the prospective adult student are as follows (ranked in descending order) [5]

1. Convenient time and place for class

2. Flexible pacing for completing a program

3. Ability to transfer credits

4. Cost

5. Reputation of the Institution

6. Requirement for current or future job 
7. Ability to design my own program

8. Credit for learning gained from life and work experience

9. Availability of financial assistance

10. Distance from campus

11. Availability of online courses

12. Tuition reimbursement from employer

13. Program accreditation by professional organization or trade group

14. Encouragement/incentive from supervisor

15. Course help at employment site

16. Availability of child care

Online education is another area that should be considered for the adult. Although it is true that adults want flexibility, not all adults want online courses.[7] Many adults want access to the instructor and feel that they may not get that from an online course. If an online course were done well, that would not be a concern. "Those involved in online learning believe that when properly executed, it can create positive social interaction among students and foster a one-on-one relationship between teacher and student."[2]

\section{ADULT DEGREE DESIGN PROCESS}

An adult degree task force of members from the CIS department was formed in the spring of 2006. They were charged to look at the degrees that were currently being offered and decide what should be marketed to the adult student.

Most adults get their information on potential College enrollment from the institution's web site. [5] An analysis of the University web site showed that there was no marketing towards the adult Information Systems student. The University does have an Adult and Continuing Education School that caters to the adult learner's needs, but there is no mention on the web that the IS department carries a large number of adult students in their ranks. Because the University draws most of their students from the local region, it was necessary to do an analysis of how the other institutions market their IS programs to adults. A summary of this analysis is presented in table (a) in the appendix.

The data in table (a), highlights the fact that Robert Morris was not doing any marketing towards the adult learner. In the lower chart area where adult specific concerns are addressed, Robert Morris was considerably under represented. And, since the adult is primarily getting his information from the web site, this needed to be changed. But again, was there anything to market? Did the department have an adult friendly degree? Was there a program in Information Systems that addressed the concerns and the needs of adults? Had the department missed the opportunity to grab the adults? The administration of the University felt that the Computer and Information Systems Department had miss the boat. Further more, if the CIS department had not gotten their act together to redesign a adult friendly degree, the degree would have been taken from the CIS department and moved to the Adult and Continuing Education school. The administration also was pushing for a totally online IS degree, something that was very unpopular in the department.

\section{Degree Iterations}

With the taskforce working on how the adult degree should be constructed, input was solicited from all members of the CIS Department. The proposed adult degree went through a number of iterations. The first iteration (Informational summary) was circulated to all members of the department.

\section{First Iteration of the Adult Degree:}

IS-Flex- Proposal for a Bachelor of Science in Information Systems Management (presented to the student in a flexible format)

This document is a first attempt to answer the problem of shrinking student numbers and the desire from students to obtain their degree in a flexible format as is being done in many other institutions. The format would be a combination of on-line and partially on-line courses with limited instructor lead sessions. The format would be the following:

Totally online course work: Students would complete all course work using E-College, the shell provided by Robert Morris for online courses.

Partially online with limited Instructor led sessions: Students would use E-College to submit all work and obtain assignments. The students would meet with the instructor every $5^{\text {th }}$ week. This meeting would be for 2 to 3 hours and could be an evening or a Saturday morning. The types of things done at this session could be:

- Further explanations of coursework

- Help Sessions

- Student Presentations

- Student Hands-on Work Sessions

- Student Exams

All courses listed on the attached page are those listed in the Check Sheet for the degree:

Bachelor of Science in Information Systems Management, Field Concentration: General 
- Please note that all course work under the General Field Concentration is listed as any course in the Computer Information Systems discipline (2000 level or above)

- The student would also take a Business Area of Interest.

Please take a moment to look over the attached sheet and indicate your preference as to where each course should fit.

As can be seen in the last line of the text above, the members of the department were asked to fill out an attached survey listing all course offerings by the department and indicate if these could be taught totally or partially online.

Not one department member returned the survey. There was a great deal of dissension among the faculty. Many were concerned about the quality of the degree. Other concerns included:

- Assessment of student knowledge

- Faculty compensation

- Location of classes

- Quality of online courses

- Loss of control of degree to the adult school

- Student technology problems

After a number of department meeting, both formal and informal, and continued meetings of the task force, the following document was circulated to the faculty in the CIS department:

\section{Second Iteration of the Adult Degree:}

\section{Computer Information Systems Flexible Accelerated Program Overview}

The School of Communications and Information Systems is happy to offer a Computer Information Systems degree to the busy Adult in a flexible, accelerated format. Students accepted with 60 credits or more can complete their degree in 2 years or less by taking core and open elective courses in the accelerated 8-week format.

Robert Morris University is the only school in the nation with a professionally accredited adult degree in Computer Information Systems. The program is accredited by ABET_(Accreditation Board for Engineering and Technology). ABET, Inc., is the recognized U.S. accreditor of college and university programs in applied science, computing, engineering, and technology. Accreditation ensures the quality of the postsecondary education students receive.

The Computer Information Systems Flexible Accelerated degree program focuses on using technology as a tool to manage information in the context of managing an organization. The program includes a core number of courses focusing on programming, systems analysis and design, database management systems, project management, knowledge management and information systems planning.

This degree is presented to students with accelerated formats, online delivery, and classes in a large variety of student friendly formats - all utilizing applied learning and real world knowledge. The 120-credit curriculum includes 36 credits of Computer Information Systems courses and 45 credits of open electives, in addition to the 39-credit Robert Morris University core.

RMU will apply up to 69 transfer credits from accredited institutions. In addition, students admitted to the School of Communications and Information Systems may receive up to 30 credits for life experience. RMU defines life experience credit as credits earned by CLEP or advanced standing examination, credits awarded for certificate or workrelated training as recognized by the American Council on Education, and portfolio credits. Portfolio credits are awarded for learning gained through work and life experience. Students must be able to document the learning and equate it to university-level learning.

The Computer Information Systems major courses are all offered in a variety of formats. Some will be totally online, some will require one or two meetings throughout the Semester and some will be one a night a week. All of the courses, no matter what the format, will be offered in the eight week sessions only. Course material in various courses may be offered in both synchronous and asynchronous manners. Therefore, the program is well suited to the working adult, allowing a great deal of flexibility in the degree completion process. All of the many support services of the University are also available to ensure the student's success.

As all of the meetings progressed, pressure was coming from the administration that made it very clear that the situation was urgent. If the department did not do something about a flexible degree quickly, the degree was to be moved to the Adult school. We would have lost control of the degree and eventually lost faculty. Even though many faculty still voiced concerns over the quality of the degree, all were finally able to agree on a final version. The final iteration of the degree is as follows: 


\section{Third and Final Iteration of the Adult Degree:}

\section{B.S. Degree in Computer Information Systems (BS CIS) - Adult Learners Program}

The current BS ISM (Information Systems Management) will be renamed for BS CIS (Computer Information Systems) for all undergraduate students. Other than renaming of the degree and the courses, there are essentially no changes in the content of this degree.

The Adult Learners Program is an offering of the BS CIS degree that is tailored to the needs of adult learners with the primary source of these adult learners expected to be degree completion students who will be transferring in a significant number of credits. The major differences between the Adult Learners Program and the degree as offered to traditional students are:

- A prescribed structure to the program which (1) eliminates the concentrations and (2) replaces the MANAGEMENT AREA OF INTEREST with a FIELD OF INTEREST that includes business oriented courses that are offered through the ACE school.

- A more flexible approach to offering of CIS courses that provides the option to offer selected courses in multiple formats.

- Traditional 15 week CIS courses will be replaced by 8 week courses with a significant on-line component (approximately $45 \%$ of the course material will be on-line)

The Adult learners program will be offered by the CIS Department in conjunction with the ACE school. CIS will be responsible for course content, assignment of faculty and other course related aspects of the program. ACE (Adult and Continuing Education) will be responsible for marketing, admissions or other aspects of administering students in the Adult Learners Program.

The ACE tuition structure will apply to the Adult Learners Program.

CIS Department undergraduate enrollment statistics will include students in the Adult Learners program.

The current intent is to begin offering the Adult Learners program at both the Pittsburgh and Cranberry locations starting Fall of 2006.

Rules for the Adult Learner Program:

1. All students in this program MUST BE ACE qualified or approved by the ACE School for taking ACE courses. ACE qualified is as follows: Undergraduate students age 24 or older, Married students, Students who are a parent, Students who are a veteran, Students who are returning to college after being out of school for several years, Students seeking night, weekend or online courses .

2. CIS Adult Learner sections offered to students in this program ARE NOT open to students who are not enrolled in either (a) this program or (b) an ACE program that accepts these courses

3. Students who are enrolled at RMU in other degree programs and who are ACE QUALIFIED may transfer into this program subject to an evaluation of their courses. Transferability of courses IS NOT guaranteed.

4. CIS Adult Learner sections offered to students in this program will be offered in one or more of the following formats. Format or formats offered for each course will be determined on a departmental basis; not on an individual section basis. (See table (b) in the appendix)

\section{BS CISM Degree Requirements}

RMU Core (39 Credits)

- Students will take ACE courses to address the RMU Core requirements and can complete all Core requirements with ACE courses

- Students will have the option to take traditional courses that are an exact match for the ACE courses

Program Requirements (9 Credits)

- $\quad$ STAT 3120 Statistics II

- CIS 3450 Quantitative Analysis for I.S. Professionals

- CIS 4170 Global, Economic, Social and Ethical Issues in Computing

Major (39 Credits):

- The concept of concentrations has been dropped and will be replaced with a structured group of courses so as to provide sufficient enrollment levels to guarantee delivery of an entire degree program on a timely basis

- The content of CIS course sections for Adult Learners will be essentially the same as courses for traditional learners. The Adult Learner sections will be adjusted to (a) address the needs of adult learners and (b) allow for requirements of alternative delivery formats.

- CIS 2120 Visual Basic Programming I

- CIS 2121 Visual Basic Programming II(Transfer students can substitute 6 credits in the 
same programming language (ex. COBOL) for these requirement)

- $\quad$ CIS 2150 Operating Systems - (A+ exam can be the basis of a Certification/Work Experience format for this course)

- $\quad$ CIS 3150 Web Development \& E-commerce I

- $\quad$ CIS 3220 Systems Analysis

- $\quad$ CIS 3230 Network Technology \& Mgmt-(N+ exam can be the basis of a Certification/Work Experience format for this course)

- CIS 3235 Computer/Network Security(CompTIA Security+ Certification exam can be the basis of Certification/Work Experience format for this course)

- $\quad$ CIS 4240 DBMS I

- $\quad$ CIS 4241 DBMS II

- $\quad$ CIS 4810 Project Management- (CompTIA Project+ Certification exam can be the basis of Certification/Work Experience format for this course)

- $\quad$ CIS 4850 Web Development \& E-commerce II(This course will be the capstone course for the entire degree. It will involve the development of a web based system that incorporates systems analysis, database, computer security and project management. Therefore, there will be a prerequisite of senior standing and completion of each of the courses in these areas.)

- $\quad$ CIS or PCIS Elective

- CIS or PCIS Elective

(A limited number of electives will be offered in the CIS adult learner format. Students will have the option to take traditional CIS courses, PCIS courses or work study programs for electives.)

Field of Interest (15 credits) (Five of the following ACE courses)

- ACCT1010 Intro Financial Accounting

- COMM 2700 Organizational Communication

- $\quad$ MARK 3100 Principles Of Marketing

- $\quad$ MGMT 3100 Management Theory and Practice

- $\quad$ PSYC 3810 Industrial Psychology

- $\quad$ SACE 2200 Appld Organiz Ldrship Skills I

- $\quad$ SACE 2300 Appld Organiz Ldrshp Skills II OPEN ELECTIVES (24 Credits)

\section{CONCLUSION}

Getting all faculty members of the CIS department to unanimously agree to the above final version of the degree was a triumph for the faculty and future adult students. The faculty recognized that the degree can be offered to adults in a flexible format while maintaining the quality of the program. The faculty agreed to a flexible format for the degree, but fell short of a totally online degree. That type of a degree may come sometime in the future. As of now, about half of all CIS courses are offered totally online during various semesters.

Program qualities important to adults are present in this a program. This degree is currently the only accredited IS degree in the country specifically marketed to adults. The marketing for the degree has been turned over to the School of Adult and Continuing Education at the University. They are already doing extensive marketing to the adult community.

Even thou the responsibility for the marketing is not in the CIS department, care is being taken to ensure that it is done well. There recently was a re-design of the entire University web site and it was a little difficult for this author to find the new adult degree. It is also the consensus of the CIS department that not enough information concerning the degree is present on the web. This situation can be rectified by members of the CIS department communicating the necessary information to the web designer. The department controls the course content of the IS program and therefore should be responsible for providing this information.

Along with the web site, marketing must be done in other areas. These include radio, television, brochures, online catalog, and information sessions. The new adult degree was launched in the Fall of 2006. But, the new web site became operational in March of 2007. To date, there has been very little done in the area of radio and television advertising. The CIS faulty addressed a need and came together with a solution. The administration has made the commitment to support the marketing. It is assumed that this will be done and all will benefit from the process. But since there was no major marketing before the fall 2006 semester, it is still too early to assess how this adult program will succeed in the attraction and retention of the adult student. This is something that will be tracked and assessed. Future research could also be in the area of the assessment of the learning outcomes of the adult program as they compare to the learning outcomes traditional program.

\section{REFERENCES}

1. Certification http://www.certmar.com/articles

2. Conhaim, Wallys W.(2003) Education Ain't What It Used to Be Information Today, Dec2003, Vol. 20 Issue 11, p37-38, 2p; (AN 11614682) 
3. dba-

oracle.com/oracle_news/2005_6_17_comput er_science_majors_decline.htm

4. Henner, Terry, (2006) What Students Want: Generation $Y$ and the Changing Function of the Academic Library. Medical Reference Services Quarterly, Summer 2006, Vol. 25 Issue 2, p116-116, 1/3p; (AN 22532229)

5. Noel-Levitz, (2005) National Adult Learners Satisfaction-Priorities Report Research Report. By: USA Group NoelLevitz, Iowa City, IA.. Online Submission. 200512 pp. (ED490033)

6. Robert Half, http://www.roberthalftechnology.com

7. Tabatabaei, Manouchehr; Schrottner, Bea; Reichgelt, Han.Target, (2006) Populations for Online Education. By: International Journal on E-Learning, v5 n3 p401-414 Jul 2006. (EJ735718)

8. US Department of Labor and Labor Statistics - Occupational Outlook Handbook 2006-2007

(http://www.bls.gov/oco/ocos258.htm\#outlo ok)

9. US Department of Labor, Bureau of Labor Statistics (http://www.bls.gov/)

10. Yan W, Center for Rural Pennsylvania H. Adult Education in Rural Pennsylvania. Center for Rural Pennsylvania [serial online]. 2006. Available from: ERIC, Ipswich, MA. Accessed March 7, 2007

\section{APPENDIX}

Table (a) Comparison of Regional Institutions

\section{Information advertised on Web Site}

\section{Institutions}

\begin{tabular}{|c|c|c|c|c|c|c|c|c|c|c|}
\hline & 1 & 2 & 3 & 4 & 5 & 6 & 7 & 8 & 9 & RMU \\
\hline \multicolumn{11}{|l|}{ Offer Totally online Degree } \\
\hline \multicolumn{11}{|c|}{ Offer Partially online course-work } \\
\hline \multicolumn{11}{|l|}{ Offer Totally online course-work } \\
\hline \multicolumn{11}{|l|}{ Offer Weekend courses } \\
\hline \multicolumn{11}{|l|}{ Have a Traditional Program } \\
\hline \multicolumn{11}{|l|}{3 to 4 hour class meetings } \\
\hline \multicolumn{11}{|l|}{5 week sessions } \\
\hline \multicolumn{11}{|l|}{ 6-8 week sessions } \\
\hline \multicolumn{11}{|l|}{ Regular 15-16 week sessions } \\
\hline \multicolumn{11}{|l|}{ Have multiple campus locations } \\
\hline \multicolumn{11}{|l|}{ Offer Synchronous online courses } \\
\hline \multicolumn{11}{|c|}{ Offer Asynchronous online courses } \\
\hline \multicolumn{11}{|l|}{ Offer Exams on ground } \\
\hline \multicolumn{11}{|l|}{ Offer Exams online } \\
\hline \multicolumn{11}{|c|}{ Cohort of adults for the degree program } \\
\hline \multicolumn{11}{|l|}{ Credit is given for life learning } \\
\hline \multicolumn{11}{|l|}{ Offer Flexible tuition } \\
\hline Books given directly to student & & & & & & & & & & \\
\hline
\end{tabular}




\begin{tabular}{|l|l|l|l|l|l|l|l|l|l|l|}
\cline { 2 - 10 } & 1 & 2 & 3 & 4 & 5 & 6 & 7 & 8 & 9 & RMU \\
\hline Advertise Specifically for Adults & & & & & & & & & & \\
\hline Advertise Accelerated Format & & & & & & & & & & \\
\hline Advertise Flexible Format & & & & & & & & & & \\
\hline Advertise 12 -16 credits in 1 Semester & & & & & & & & & & \\
\hline Advertise completion in 1-2 years & & & & & & & & & & \\
\hline Advertise easy transfer of credits & & & & & & & & & & \\
\hline Advertise Jobs after graduation & & & & & & & & & & \\
\hline
\end{tabular}

Institutions Key:

1. Duquesne University (http://www.leadership.duq.edu/home/main.cfm)

2. Carlow Univeristy (http://www.carlow.edu/)

3. Point Park University (http://www.pointpark.edu/)

4. Geneva College (http://www.geneva.edu/page/index.html)

5. Waynesburg College (http://waynesburg.edu/)

6. Strayer University (http://strayer.college-info.org)

7. Phoenix University (http://www.phoenix.edu/)

8. University of Pittsburgh (http://www.pitt.edu/)

9. Indiana University of Pennsylvania (http://www.iup.edu/)

RMU. Robert Morris University

Table (b) Formats of Adult degree courses

\begin{tabular}{|c|c|}
\hline FORMAT & DESCRIPTION \\
\hline On-Ground/On-Line & $\begin{array}{l}\text { - } \quad \text { Eight week course } \\
\text { - } \quad \text { Class meet for } 2 \text { hours and } 50 \text { minutes } \\
\text { - } \quad \text { On line component of approximately } 45 \% \text { of the course material }\end{array}$ \\
\hline On-Line & - Any on-line format consistent with ACE \\
\hline $\begin{array}{l}\text { Certification/Work } \\
\text { Experiences }\end{array}$ & $\begin{array}{l}\text { - This category will be offered in areas where there is a nationally accepted certification exam with } \\
\text { appropriate self preparation materials (ex. N+, A+, Security +) } \\
\text { In order to receive credit, the student must: } \\
\text { o Pass the certification exam } \\
\text { AND DO ONE OF THE FOLLOWING: } \\
\text { o Write a paper showing how the material addressed in this course has been or can be } \\
\text { applied to their employment situation } \\
\text { OR Submit a portfolio demonstrating work related accomplishments in the areas covered by } \\
\text { - } \text { the course } \\
\text { - Student will pay a fee equivalent to } 1 \text { credit to provide faculty support during the writing of the } \\
\text { paper or development and evaluation of the portfolio } \\
\text { Student may take no more than } 9 \text { credits ( } 3 \text { courses) in this format }\end{array}$ \\
\hline
\end{tabular}

